\title{
An assessment of the role of an open shelter in reducing soiling and microbial growth on the archaeological site of the Bishop's Palace, Witney, England
}

Cristina Cabello Briones ${ }^{\mathrm{a} *}$ and Heather Viles ${ }^{\mathrm{b}}$

${ }^{a b}$ School of Geography and the Environment, Oxford University Centre for the Environment, University of Oxford, South Parks Road, Oxford, OX1 3QY, United Kingdom, Tel.: +44 (0)1865 285071

${ }^{a}$ c.cabello-briones@oxfordalumni.org

orcid.org/0000-0002-5857-9946

bheather.viles@ouce.ox.ac.uk

orcid.org/0000-0002-2444-1295

*corresponding author 


\section{An assessment of the role of an open shelter in reducing soiling and microbial growth on the archaeological site of the Bishop's Palace, Witney, England}

Two sets of twelve Portland limestone tablets were attached to carousels outside and under the open, lightweight shelter at Bishop’s Palace (Witney, England) for 18 months to assess the influence of shelters on soiling and microbiological growth on stone. At the start, and at 6-month intervals, tablets were analysed using microscopy (optical and SEM), colour measurement (spectrophotometry), weight change measurement and salt content determination (ion chromatography). Concentrations of $\mathrm{NO}_{2}$ and $\mathrm{SO}_{2}$ were also monitored for a month using diffusion tubes. In addition, results were compared with those obtained by the UK National Materials Exposure Programme (NMEP) on chemical weathering rates. Differences in soiling and biological growth on sheltered and unsheltered samples, and their influence on limestone decay were established. The shelter is likely to reduce biological growth by modifying the micro-environmental conditions. However, it may also exacerbate dust deposition, which might increase decay rates in the long-term.

Keywords: shelters for archaeological sites; Bishop’s Palace; soiling; microbial growth; Portland limestone tablets; decay rates

\section{Introduction and research context}

Soiling has been defined as a deposit of a very thin layer of exogenous particles giving a dirty appearance to the stone (ICOMOS-ISCS 2008). Soiling is most often associated with darkening of the surface related to the deposition of airborne particulate matter (Grossi et al. 2003). However, the formation of salt efflorescences due to chemical weathering can make the surface lighter (Pio, Ramos, and Duarte 1997). On the other hand, soiling can also result from pigmented biofilms such as black fungi and green algal patinas (Zanardini et al. 2000, Cutler et al. 2013) and biofilms can contribute to the accumulation of pollutants (through extra cellular polymeric substances) and vice 
versa (Krumbein 2004; Saiz Jimenez 2003; Viles and Gorbushina 2003). Therefore, darkening could be a result of organic or inorganic soiling or both, while greening is likely to be associated with organic growth.

Organic soiling can result in stone deterioration as biological communities can cause chemical weathering related to the action of metabolic substances, and/or mechanical weathering due to, for example, pore pressures exerted by growing cells and the expansion and contraction of cells and their EPS matrix via wetting/drying (Krumbein 2004). However, microbial biofilms can also have a protective role, consolidating the stone surface and shielding it from rain and pollution to varying degrees (Viles 2012). Inorganic soiling can also cause stone deterioration, as deposition of atmospheric pollutants can cause chemical weathering (Camuffo 1986; Grossi and Brimblecombe 2002). Gaseous and particulate pollutants (including carbon soot, fly ash, dust and associated salts) can be deposited directly on the stone surface (dry deposition) or dissolved in rainwater (wet deposition). Sheltered areas of stone are affected mainly by dry deposition, and because of the lack of rain, pollutants can accumulate on sheltered surfaces. Those pollutants are 'activated' by moisture from condensation or rising damp leading to the formation of soluble salt crusts (Steiger 2003; Brimblecombe 2011). Resultant salt crusts can make stones more prone to mass loss (Lipfert 1989) and can produce mechanical stresses due to their different molecular volume (Brimblecombe 2011). Unsheltered stone is affected by wet and dry deposition and other deterioration processes. Limestone, for example, is dissolved by rainfall acidified by $\mathrm{CO}_{2}$ and other compounds, with rainfall amount, temperature, and $\mathrm{pH}$ key rate controlling factors (Viles and Gorbushina 2003, Webb et al. 1992). The rate of decay of calcareous stones in relation to pollution and climate has been studied by numerous projects (Lipfert 1989; Webb et al. 1992; Inkpen, Cooke, and 
Viles 1994). Among them, the National Materials Exposure Programme (NMEP), established in 1986, aimed to assess the impact of acid deposition on building materials in the United Kingdom (Butlin, Coote, et al. 1992; Butlin, Yates, et al. 1993). As part of the first phase of this programme, Whit Bed Portland limestone tablets (50x50x8 mm) were mounted on freely rotating carousels in exposed and sheltered positions at 29 sites across the UK with different climatic conditions for four years (Butlin, Yates, et al. 1993). After this time, sheltered tablets were found to contain higher levels of soluble salts in comparison to rain washed tablets. In addition, sheltered tablets tended to gain weight whereas exposed tablets lost weight and increased in surface roughness. The attributed causes were soiling and dissolution, respectively. In addition, the study established damage functions to predict the change in weight in relation to air concentrations of $\mathrm{NO}_{2}$ and $\mathrm{SO}_{2}$ (associated with traffic and industrial emissions respectively), and rainfall acidity and amount. A follow-up study on NMEP tablets from Wells, Bolsover and Lough Navar undertaken by Viles et al. (2002) found that pollution was an important control on the nature and degree of soiling (both biological and inorganic).

This study examines the effects of a lightweight open shelter on inorganic soiling and biological growth on limestone at an archaeological site. Shelters are structures that cover archaeological remains to protect them. Enclosed shelters cover the ruins completely (isolating them from the surroundings) whereas open shelters offer a partial cover without lateral cladding. This allows air exchange without the need for artificial ventilation. Open shelters may both slow down or exacerbate the rate of some deterioration processes. For example, a temporary lightweight, open shelter constructed in Cyprus by the Getty Conservation Institute showed an effective protection against the direct influence of sunlight, rain and wind (Agnew et al. 1996). However, the open 
shelter over the NN4 area at Caesarea (Israel) caused condensation problems, which led to salt crystallization, bulging, and detachment of the mosaics (Stewart, Neguer, and Demas 2006; Neguer and Alef 2008).

An open shelter made of a lightweight fabric was constructed over the medieval palace of the Bishop of Winchester ('Bishop’s Palace’) in 1991 (Figure 1). Bishop’s Palace was built with Cotswold limestone in the city centre of Witney, a small town in Oxfordshire (South East England). A visual assessment of the decay patterns on the site revealed that biofilms and crusts were the main problems (Cabello Briones 2016). Biological growth (Figure $2 \mathrm{a}$ and $\mathrm{b}$ ) is predominant in areas where stones are damp, such as at the bottom of walls and on North-facing walls. In addition, crusts of possible biological origin were found on the ruins with no clear spatial pattern.

In order to understand the impact of the open shelter at Bishop's Palace on limestone deterioration (due to dissolution, soiling and biological growth) we aimed: 1) to compare inorganic soiling and microbial colonisation on limestone outside and under

the shelter and 2) establish how those are affecting limestone deterioration at the site. Comparison with results from the NMEP was facilitated by using Portland limestone tablets, positioned inside and outside the shelter at Bishop’s Palace on carousels.

\section{Materials and methods}

Following the UK NMEP methodology, two sets of twelve Whit Bed Portland stone tablets (50x50x20 mm) were placed inside and outside the shelter at Bishop's Palace site on freely-rotating carousels. Portland stone is a Jurassic oolitic limestone with relatively low water absorption coefficient and open porosity, and high apparent density and is considered to be relatively durable (Table 1).

The tablets were exposed vertically on carousels in line with previous research (Jaynes and Cooke 1987; Butlin, Coote, et al. 1992). Twelve tablets were located under the 
shelter on a central pole at approx. $1.5 \mathrm{~m}$ above the current ground; and twelve tablets were placed outside the cover, on a support at $1 \mathrm{~m}$ above the ground in a private garden on the north side of the site. Three tablets per set were exposed for 6 months, another three for 12 months and the remaining six for 18 months. In addition, three tablets were left in a sealed container (with silica gel) in the laboratory for the duration of the study to act as controls. Before exposure, each stone tablet was washed in deionised water and dried in a ventilated oven at $105^{\circ} \mathrm{C}$ to constant weight - and then weighed (using a Sartorius AG balance, accuracy 0.01g) and analysed, as described below. The same drying procedure was used after each exposure period before re-weighing and reanalysis.

Surface colour measurements were used to quantify soiling and biological colonisation rates. Colour change in stone surfaces has been used in other studies as a proxy for both biological growth (Viles and Gorbushina, 2003; Viles et al. 2002; Giovagnoli, Paradisi, and Polidoro 2006) and soiling of monuments and archaeological remains (Grossi et al. 2003; Viles et al. 2002). Colour was measured with a Spectrophotometer (Konica Minolta CM- 700d), using the mean of 10 measurements on the tablets before exposure as a reference value. These reference values were compared with those measured after each exposure period to quantify colour change. The settings used were: area of measurement MAV area of measurement $(\Phi 8 \mathrm{~mm} / \Phi 11 \mathrm{~mm})$, D65 illuminant, di:8 viewing system (diffused illumination, $8^{\circ}$ viewing angle), and SCE illumination (specular component excluded). Results were expressed as overall colour difference (dEab*), lightness difference ( $\left.\mathrm{dL}^{*}\right)$ and greening $\left(\mathrm{db}^{*}\right)$ of the surface using the International Commission on Illumination (CIE) standard, CIELAB (L*a*b). 
Optical microscopy and scanning electron microscope (SEM) methods were used to corroborate the presence of microorganisms on the stone surfaces after 18 months of exposure, and infer their weathering roles.

Salt contents after 6, 12 and 18 months of exposure were quantified using a Dionex ion chromatograph. The major anions (sulphate, nitrate, nitrite, chloride, fluoride and phosphate) and cations (sodium, ammonium, potassium, magnesium and calcium) were extracted from $5 \mathrm{~g}$ of stone using deionised water and their concentrations measured (in ppm). As salt concentration can change with depth (Watt and Colston 2000), an analysis of pollutants in the upper $2 \mathrm{~mm}$ of stone after a year of exposure was also carried out. Salt concentrations were compared with those in laboratory control tablets. The $\mathrm{pH}$ of a representative sample of rain falling at the study site was measured in April 2014 (pH meter Orion Model 410A). Combined $\mathrm{NO}_{2}$ and $\mathrm{SO}_{2}$ diffusion tubes (Gradko International Ltd) were also deployed on site for 4 weeks in October/November 2013; autumn provides more stable values of pollution in comparison with the winter peaks and summer troughs in $\mathrm{NO}_{2}$, as noted by Hargreaves et al. (2000). Diffusion tubes are a simple, efficient, passive technique for monitoring gaseous air pollutants in the air and have been used extensively in environmental studies for heritage preservation (Gysels et al. 2004; Camuffo et al. 1999; Viles and Gorbushina 2003). Three tubes, mounted vertically on the same support as the carousels, were left in each location and an extra, unopened tube was added to each set to determine if sunlight affected the results (Krochmal and Kalina 1997). A laboratory blank with closed caps was also placed in a dark and cold room over the same period. After exposure, analysis was carried out using Dionex ion chromatography; concentrations of $\mathrm{NO}_{2}$ and $\mathrm{SO}_{2}$ in both the in situ unopened tube and the laboratory blank were found to be below levels of detection. 
The amount of weathering experienced by each tablet was calculated as percentage dry weight loss (measured using a Sartorius AG balance, accuracy 0.01g):

$\%$ Wdry = (dry weight after exposure-dry weight before exposure)/ (dry weight after exposure) x 100

Two-way ANOVA tests were used to determine if there were statically significant differences in weight change, salt content (nitrates and sulphates) and colour change ( $\mathrm{dE}^{*} \mathrm{ab}, \mathrm{da}^{*}$ and $\mathrm{dL}^{*}$ values) between positions (control, inside and outside the shelter), and time of exposure $(6,12$, and18 months). In addition, post-hoc all pairwise multiple comparison tests (Holm-Sidak method) were used to isolate which group differed from the others. T-tests were also undertaken to determine if the differences between inside and outside the shelter in mean air pollution levels $\left(\mathrm{SO}_{2}\right.$ and $\left.\mathrm{NO}_{2}\right)$ and nitrate and sulphate concentration on the stone surface (as recorded to a depth of $2 \mathrm{~mm}$ ) after a year were significant.

In order to compare the rate and nature of decay at the Bishop's Palace with published data from other sites in the UK, the results of this study were compared with data from four NMEP sites with low rainfall acidity and air pollution: Wells (South West England), Bovington Camp (South East England), Lough Navar (Northern Ireland) and Strath Vaich Dam (Scotland).

\section{Results}

\section{Colour change}

Figure 3a shows the overall colour change of sheltered and unsheltered tablets after 6 , 12 and 18 months (relative to the baseline). Tablets placed outside the shelter experienced greater overall colour change than those inside the shelter. This difference 
was most pronounced after 12 months of exposure, when CIELAB colour differences were over $3.8 \mathrm{dE}^{*} \mathrm{ab}$, the indicative threshold for changes to be distinctively perceptible by the naked eye (Bieske and Vandahl 2008). An ANOVA test showed that the effect of position on colour change varied between the different periods of exposure ( $F=6.650$, $\mathrm{DF}=4, \mathrm{P}=0.002$ ). Post-hoc multiple comparison tests indicated no significant difference in colour change after 6 months between sheltered and unsheltered tablets $(\mathrm{t}=0.539$, $\mathrm{P}=0.934)$, but significant differences were observed after 12 months $(\mathrm{t}=6.235, \mathrm{P}<0.001)$ and 18 months $(\mathrm{t}=4.669, \mathrm{P}<0.001)$. In addition, there were no significant differences between sheltered and control tablets after 6, 12 or 18 months $(\mathrm{P}<0.050)$ but unsheltered tablets varied significantly from the controls after $12(\mathrm{t}=4.947,<0.001)$ and 18 months $(\mathrm{t}=0.657, \mathrm{P}=0.011)$.

Figure 3, b shows da* changes for sheltered and unsheltered tablets after 6, 12 and 18 months. The unsheltered tablets exposed for 12 months were greener than those exposed for 6 and 18 months. Deviations on the red-green scale (da*) are inferred to relate to the presence of pigmented microbes, such as green algae or cyanobacteria (Cutler et al. 2013). Negative values indicate that the stone surface is greener than the baseline measurement. When $\mathrm{dE}^{*}$ is below -1 , the greening of the surface is considered noticeable (Cutler et al. 2013). An ANOVA test showed that, as for overall colour change, there was a statistically significant interaction between position and time factors ( $F=12.87, \mathrm{DF}=4, \mathrm{P}<0.001)$. Subsequent post-hoc multiple comparisons showed statistically different da* values for sheltered vs unsheltered tablets after 12 months $(\mathrm{t}=8.591, \mathrm{P}<0.001)$ and 18 months $(\mathrm{t}=2.798, \mathrm{P}=0.035)$ of exposure. Additionally, the only significant difference between exposed and control tablets was in the unsheltered ones after 12 months $(\mathrm{t}=7.166, \mathrm{P}<0.001)$. The tablets placed outside the shelter became significantly greener than the ones inside and the controls after a year. 
Figure 3, c) shows $\mathrm{dL} *$ data. Changes in $\mathrm{dL} *$ reflect a darkening (negative values) or lightening (positive values) of the surface. When darker particles are deposited on the stone, the amount of reflected light is reduced (Pesava et al. 1999). Darkening of the surface of the limestone tablets positioned outside the shelter was noticeable after 12 months of exposure, when $\mathrm{dL}^{*}$ values are less than -1 (Cutler et al. 2013). An ANOVA test showed that the interaction between positions and months is not statistically significant $(\mathrm{F}=2.042, \mathrm{DF}=4, \mathrm{P}=1.31)$. However, position as a factor had a significant effect on $\mathrm{dL}^{*}$ values $(\mathrm{F}=15.043, \mathrm{DF}=2, \mathrm{P}<0.001)$. Post-hoc multiple comparisons showed that unsheltered samples became significantly darker than controls ( $\mathrm{t}=3.058$, $\mathrm{P}=0.013)$ and sheltered tablets $(\mathrm{t}=5.307, \mathrm{P}<0.001)$ after exposure, but there was no difference between controls and sheltered tablets ( $\mathrm{t}=0.441, \mathrm{P}=0.664)$.

\section{Microscopy}

Optical microscopy (Figure 4, a) and SEM observations (Figure 4, b) showed less microbiological growth on sheltered vs exposed tablets. Microorganisms were found mainly at the corners of the samples and inside the pores, probably where moisture was greater.

\section{Salt contents}

Detailed analysis of salt content in tablets showed that only the amount of chlorides, nitrates and sulphates varied considerably in relation to position. Figure 5 shows data on sulphates, nitrates and chlorides in tablets exposed inside and outside of the shelter, after 6, 12 and 18 months of exposure in comparison with controls. An ANOVA test showed that the amount of pollutants depended on the position they were placed $(\mathrm{P}<0.001)$. Sheltered tablets had greater amounts of salt ions (particularly sulphates) than both controls and unsheltered tablets, likely because the sheltered tablets are 
protected from the washing effect of rain. In addition, there is a statistically significant interaction between position and time factors for sulphates $(F=5.372, D F=4, F=0.006)$, nitrates $(\mathrm{F}=9.881, \mathrm{DF}=4, \mathrm{P}<0.001)$ and chlorides $(\mathrm{F}=4.138, \mathrm{DF}=4, \mathrm{P}=0.017)$, indicating the magnitude of these differences varied with time. Post hoc multiple comparison tests showed that concentrations of sulphates were significantly different between sheltered and unsheltered tablets after 12 months ( $\mathrm{t}=8.639, \mathrm{P}<0.001)$, and after only 6 months for nitrates ( $\mathrm{t}=3.662, \mathrm{P}=0.004)$ and chlorides $(\mathrm{t}=30336, \mathrm{P}=0.013)$.

The analysis on the upper $2 \mathrm{~mm}$ of stone showed that almost three times the amount of sulphates and nitrates had accumulated in the surface layers of the sheltered vs exposed stone tablets (Table 2). This difference was significant for both sulphate ( $\mathrm{t}=8.571$, $\mathrm{P}=0.001)$ and nitrate $(\mathrm{t}=-3.225, \mathrm{P}=0.032)$ (Student's t test).

Bishop’s Palace is located in the city centre and there is a car park nearby. High concentration of air pollutants was expected to be found at the site, mainly inside the shelter. However, data collected using diffusion tubes indicate that $\mathrm{SO}_{2}$ concentrations are below the limit of detection (Table 3) and a Student's t-test based on data from Table 3 showed no significant difference in $\mathrm{NO}_{2}$ levels inside and outside the shelter $(\mathrm{t}=-0.972, \mathrm{P}=0.386)$. In addition, the values of $\mathrm{NO}_{2}$ are well below those published by the Council for other areas in Witney (Table 4). However, these values are still relatively high compared with other sites in the UK (Table 5). This is important as nitrogen oxides might enhance biological colonisation as well as accelerating limestone dissolution (Smith et al. 2011).

\section{Weight change}

Figure 6, a and b, show weight loss as percentage of initial dry weight of tablets after 6, 12 and 18 months of exposure both outside and inside the shelter at Bishop’s Palace. Both sheltered and exposed tablets lost weight in this study, with exposed losing twice 
as much as sheltered $(0.06 \pm 0.03 \%$ vs $0.03 \pm 0.01 \%)$. An ANOVA test on weight loss of sheltered, unsheltered and control tablets showed a statistically significant difference allowing for the influence of exposure time $(\mathrm{F}=7.654, \mathrm{DF}=2, \mathrm{P}=0.005)$. A post-hoc multiple comparison test showed that the weight lost by the unsheltered tablets was significantly greater than both sheltered $(\mathrm{t}=3.486, \mathrm{P}=0.009)$ and control tablets $(\mathrm{t}=2.929$, $\mathrm{P}=0.02$ ), whilst the difference between sheltered and control tablets was not significant $(\mathrm{t}=0.557, \mathrm{P}=0.585)$.

There were interesting differences in the rates of mass loss between periods of exposure. For example, the unsheltered tablets lost most of their weight between 6 and 12 months, whereas the sheltered tablets remained relatively stable up until 12 months, after which most of their loss occurred (Figure 6).

\section{Rates of decay comparisons}

The weight loss of tablets in this study (Figure 6) is very low in comparison to previously reported rates for the NMEP sites. The unsheltered tablets from all the NMEP sites lost between -0.29 to $-0.94 \%$ of initial dry weight (in 1987-88) compared to losses of -0.21 to and $+0.32 \%$ for sheltered samples (Butlin, Coote, et al. 1992). The NMEP study attributed weight loss to a combination of the dissolution of stone by unpolluted rainwater, dissolution by acid species in rainwater and dry deposition of acid gases and aerosols. The weight gain observed for sheltered tablets was further attributed to soiling and the presence of crusts on the surface. Table 5 shows data from the NMEP study for $\mathrm{SO}_{2}$ and $\mathrm{NO}_{2}$, annual rainfall and acidity, and mean weight loss after a year for unsheltered tablets at the four selected NMEP sites (Butlin, Coote, et al. 1992; Butlin, Yates, et al. 1993) and at Bishop’s Palace. Although annual rainfall levels at Witney were similar to those at Wells and Bovington Camp, $\mathrm{SO}_{2}$ and rain acidity at Bishop's Palace were much lower than at the NMEP sites, which likely explains the 
marked differences in annual weight change (Table 5).

Table 6 depicts data on sulphates and nitrates on sheltered vs exposed NMEP limestone tablets (Butlin, Yates, et al. 1993) in comparison with those from Bishop’s Palace.

Despite the difference in depths sampled, the concentration of sulphates in both sheltered and unsheltered tablets were much lower at Witney than at the NMEP sites. On the other hand, the amount of nitrates found in tablets located outside the shelter in Witney is much higher than in the NMEP sites.

The NMEP found a significant relationship between mean annual $\mathrm{SO}_{2}$ and $\mathrm{NO}_{2}$ concentrations, rainfall volume and acidity and weight change, with those factors accounting for more than $60 \%$ of the variation in weight change for unsheltered Portland tablets (Butlin, Coote, et al. 1992), thus:

(1) Wt loss $($ Wdry\% $)=0.08+0.010 \mathrm{SO}_{2}-0.00012 \mathrm{NO}_{2}+0.00016$ Rain +0.0026

$$
\mathrm{H}+\left(\mathrm{r}^{2}=0.604\right)
$$

where weight loss is expressed as percentage dry weight loss (Wdry\%), annual average atmospheric $\mathrm{SO}_{2}$ and $\mathrm{NO}_{2}$ is in $\mu \mathrm{g} \mathrm{m}^{-3}$, rainfall in $\mathrm{mm}$ and rainfall hydrogen ion loading in $\mathrm{mg} \mathrm{H}^{+} \mathrm{m}^{-2}$.

In addition, the NMEP found damage functions for $\mathrm{SO}_{4}{ }^{2-}$ and $\mathrm{NO}_{3}{ }^{-}\left(\mu \mathrm{g} \mathrm{g}^{-1}\right)$ content in the upper $1 \mathrm{~mm}$ of sheltered tablets (after two years of exposure) as follows (Butlin, Yates, et al. 1993):

$$
\begin{array}{ll}
\text { (2) } \mathrm{SO}_{4}{ }^{2-}=2079+191\left(\mathrm{SO}_{2}\right) & \mathrm{r}^{2}=0.75 \\
\text { (3) } \mathrm{NO}_{3}{ }^{-}=55+3\left(\mathrm{NO}_{2}\right) & \mathrm{r}^{2}=0.61
\end{array}
$$

Using this model (1), the predicted weight loss for unsheltered tablets at Bishop’s Palace is $0.16 \% \mathrm{Wdry}$ per year. This rate is much higher than the rates we observed, an 
average of $0.06 \%$. Additionally, the concentration of sulphates and nitrates in our sheltered tablets were much lower than expected if the above formulae $(2,3)$ are applied. The differences could be related to the occasional rain-washing of partially sheltered tablets at the NMEP sites (Butlin, Yates, et al. 1993). However, they most likely correspond to the national air pollution characteristic changes between the NMEP and this study. Emissions of $\mathrm{SO}_{2}$ and nitrogen oxides have fallen by $96 \%$ and $69 \%$ respectively since 1970 (Department for Environment, Food \& Rural Affairs 2016).

\section{Discussion and Conclusions}

Unsheltered tablets experienced significantly greater overall colour change and greening ( $\mathrm{dE}^{*} \mathrm{ab}$ and $\mathrm{da}^{*}$ ) than sheltered samples after 12 months. The 12-month readings were taken in January, when water availability outside the shelter was higher and presumably, time of wetness longer. Higher moisture levels encourage biological colonisation (Crispim, C.A. Gaylarde, and C.C. Gaylarde 2003). Therefore, seasonal colour changes, especially greening, appear to be related to algal growth. On the other hand, tablets placed inside the shelter might be expected to become darker than those outside the shelter, exposed to the washing effect of direct rainfall. However, measurements of $\mathrm{dL}^{*}$ variations indicate that over 18 months, tablets outside the shelter became darker. The change in colour is therefore probably related to microbial colonisation rather than dry particulate deposition, as has been suggested by previous studies on soiling (Krumbein and Gorbushina 2009; Viles et al. 2002; Viles and Gorbushina 2003). Microscope observations and air pollution data corroborate this result.

Unsheltered tablets lost more weight than sheltered ones, implying that deterioration rates are higher outside rather than under the shelter. This is most probably a result of limestone dissolution from rain and physical weathering caused by, for example, 
thermal cycling and frost outside the shelter (Cabello Briones 2016). However, enhanced biological contributions to weathering outside might also play a role through production of acids, and influences on stone surface permeability and evaporation rates (Pinna and Salvadori 2008, Smith et al. 2011).

Our measurements indicate that concentrations of pollutants in the air inside and outside the shelter at Bishop’s Palace are very similar. This is unsurprising as open shelters allow air exchange with the outside environment. However, higher salt contents in sheltered tablets imply enhanced deposition processes in comparison to outside, which can be attributed to a reduction in air circulation. This phenomenon was also observed at four sheltered archaeological sites in Italy, where marble and calcite tablets recorded particulate accumulation after four months of exposure (Instituto Centrale per il Restauro 2006). Similarly, a study in Hagar Qim (Malta) showed trends of greater pollutant accumulation on the remains after sheltering (Galea et al. 2016). No significant weight increases (associated with the formation of crusts) were detected on sheltered tablets. In general, weight change of the tablets at Bishop’s Palace is very low in comparison with the NMEP sites. The main reason seems to be the lower $\mathrm{SO}_{2}$ concentrations in the air, meaning that gypsum $\left(\mathrm{CaSO}_{4}\right)$ crusts are less likely to develop. Different types of deterioration processes are affecting stone remains inside and outside the shelter at Bishop's Palace. The comparable conditions between the NMEP sites and our case study in terms of air quality and salt content indicate that chemical weathering is not the main cause of weight loss outside the shelter. However, organic soling is particularly relevant. A combination of physical weathering due to adverse climatic conditions, and biological growth is the most probable reason of decay outside the shelter. On the other hand, the shelter at Bishop's Palace reduces the rate of biological growth underneath it by modifying habitat conditions, mainly water availability. 
However, biofilms can become a very significant factor of decay in the future as lightweight membranes do not exclude the possibility of photosynthetic biological colonies developing inside. Therefore, the shelter is protecting the site against severe biological growth in the ruins but it also encourages salt accumulation in the stone remains, which might increase decay rates in the long-term. The shelter may exacerbate dust deposition due to its effect on wind speed and turbulence. This is an area of further study.

The method based on the NMEP Portland limestone tablets has resulted to be a suitable alternative to monitor the effect of shelters on soling at archaeological sites instead of a direct analysis on stone remains. Stone tablets can be analysed using destructive methods and results compared with other sites.

\section{Geolocation information}

Fieldwork was carried out at Bishop’s Palace (Witney, United Kingdom) (latitude 51 $46^{\prime} 49.8^{\prime \prime} \mathrm{N}$, longitude $\left.1^{\circ} 29^{\prime} 0.24 " \mathrm{~W}\right)$. Analytical investigations were undertaken at the Oxford Rock Breakdown laboratory (School of Geography and the Environment, University of Oxford, United Kingdom).

\section{Acknowledgments}

We would like to thank Christiane Jeuckens (Oxfordshire County Council) and Chris Welch (Historic England, formerly English Heritage) for allowing us to study Bishop’s Palace. This work was supported by the Engineering and Physical Sciences (EPSRC) under Grant number SSD/2/2/16. 


\section{References}

Agnew, N., S. Maekawa, R. Coffman, and J. Meyer. 1996. "Evaluation of the performance of a lightweight modular site shelter. Quantitative meteorological data and protective indices for the "hexashelter". Conservation and Management of Archaeological Sites 1 (3):136-150. doi: 10.1179/135050396793137026

Bieske, K., and C. Vandahl. 2008. "A Study about Colour-Difference Thresholds." In Lux et Color Vespremiensis. Veszprem: University of Pannonia.

Brimblecombe, P. 2011. "Environment and Architectural Stone." In Stone in Architecture: Properties, Durability, edited by Siegfried Siegesmund and Rolf Snethlage, 317-346. Berlin: Springer.

Butlin, R.N., A.T. Coote, M. Devenish, I.S.C. Hughes, C.M. Hutchens, J.G. Irwin, G.O. Lloyd, S.W. Massey, A.H. Webb, and T.J.S. Yates. 1992. "Preliminary Results from the Analysis of Stone Tablets from the National Materials Exposure Programme (NMEP)." Atmospheric Environment 26B (2):189-198. doi: 10.1016/09571272(92)90022-K

Butlin, R.N., T.J.S. Yates, A.T. Coote, G.O. Lloyd, and S.W. Massey. 1993. The first phase of the National Materials Exposure Programme 1987-1991 (Revised October 1993). Report CR253/93. Building Research Establishment.

Cabello Briones, C. 2016. "The effects of open shelters on the preservation of limestone remains at archaeological sites." Doctor of Philosophy, Geography and the Environment, University of Oxford.

Camuffo, D. 1986. "Deterioration Processes of Historical Monuments." Studies in Environmental Science 30:189-221. doi: 10.1016/S0166-1116(08)70884-7 
Camuffo, D., P. Brimblecombe, R. Van Grieken, H. J. Busse, G. Sturato, A. Valentino, A. Bernandi, N. Blades, D. Shooter, L. De Bock, K. Gysels, M. Wieser, and O. Kim. 1999. "Indoor air quality at the Correr Museum, Venice, Italy." The Science of the Total Environment 236:135-152. doi: 10.1016/S0048-9697(99)00262-4

Crispim, C. A., P.M. Gaylarde, and C.C. Gaylarde. 2003. "Algal and Cyanobacterial Biofilms on Calcareous Historic Buildings." Current Microbiology 46:79-82. doi: 10.1007/s00284-002-3815-z

Cutler, N.A., H.A. Viles, S. Ahmad, S. McCabe, and B.J. Smith. 2013. "Algal 'greening' and the conservation of stone heritage structures." Science of the Total Environment 442:152-164. doi: 10.1016/j.scitotenv.2012.10.050

Department for Environment, Food \& Rural Affairs. 2016. "Emissions of Air Pollutants in the UK, 1970 to 2015." Air quality and emissions statistics. https://www.gov.uk/government/statistical-data-sets/env01-emissions-of-air-pollutants (accessed August 2017)

Galea, M.; R.; DeBattista, M.; Grima, L.; Maccarelli, R.; Borg, and C.; Zerafa. 2016. "Pollution Monitoring for Sea Salt Aerosols andOther Anionic Species at Hagar Qim Temples, Malta: A Pilot Study." Conservation and Management of Archaeological Sites 17 (4):315-326. doi: 10.1080/13505033.2016.1191890

Giovagnoli, A., A. Paradisi, and C. Polidoro. 2006. "Analisi chimiche." In Le Coperture delle Aree Archeologiche. Museo Aperto, edited by M. Laurenti, 219-229. Roma: Gangemi Editore. 
Grossi, C. M., and P. Brimblecombe. 2002. "The effect of atmospheric pollution on building materials." Journal of Physique Archives IV France 12 (10):197-210. doi: 10.1051/jp4:20020460

Grossi, C. M., R.M. Esbert, F. Diaz-Pache, and F.J. Alonso. 2003. "Soiling of buildings in urban environments." Building and Environment 38:147-159. doi: 10.1016/S0360-1323(02)00017-3

Gysels, K., F. Delalieux, F. Deutsch, R. Van Grieken, D. Camuffo, A. Bernardi, G. Sturaro, H.J. Busse, and M. Wieser. 2004. "Indoor environment and conservation in the Royal Museum of Fine Arts, Antwerp, Belgium." Journal of Cultural Heritage 5 (2):221-230. doi:10.1016/j.culher.2004.02.002

Hargreaves, P.R., A. Leidi, H.J. Grubb, M.T. Howe, and M.A. Mugglestone. 2000. "Local and seasonal variations in atmospheric nitrogen dioxide levels at Rothamsted, UK, and relationships with meteorological conditions." Atmospheric Environment 34:843-853. doi: 10.1016/S1352-2310(99)00360-X

ICOMOS-ISCS (International Scientific Committee for Stone) 2008. Illustrated glossary on stone deterioration patterns = Glossaire illustré sur les formes d'altération de la pierre, Monuments and Sites. Paris: ICOMOS.

Inkpen, R., R.U. Cooke, and H. Viles. 1994. "Processes and Rates of Urban Limestone Weathering." In Rock Weathering and Landform Evolution, edited by D.A. Robinson and R.B.G. Williams, 123-129. Chichester: John Wiley and Sons Ltd.

Jaynes, S.M., and R.U. Cooke. 1987. "Stone Weathering in Southeast England." Atmospheric Environment 21 (7):1601-1622. doi: 10.1016/0004-6981(87)90321-0 
Krochmal, D., and A. Kalina. 1997. "A Method of Nitrogen Dioxide and Sulphur Dioxide Determination in Ambient Air by Use of Passive Samplers and Ion Chromatography." Atmospheric Environment 31 (20):3473-3479. doi: 10.1016/S13522310(97)00154-4

Krumbein, W.E. 2004. "Life on and in stone - an endless story?" In Proceedings of the 10th International Congress on Deterioration and Conservation of Stone, edited by D. Kwiatkowski and R. Löfvendahl, 259-266. Stockholm: ICOMOS.

Krumbein, W.E., and A. Gorbushina. 2009. "Some Aspects of Biological Weathering and Air Pollution." In The Effects of Air Pollution on Cultural Heritage, edited by R. Hamilton, V. Kucera, J. Tidblad and J. Watt, 127-145. New York: Springer.

Lipfert, F.W. 1989. "Atmospheric damage to calcareous stones: comparison and reconciliation of recent experimental findings." Atmospheric Environment 23 (2):415429. doi: 10.1016/0004-6981(89)90587-8

Instituto Centrale per il Restauro and Ministero per i Beni e le Attività Culturali. 2006. Le Coperture delle aree archeologiche. Museo aperto, edited by M. C. Laurenti. Roma: Gangemi Editore.

Neguer, J., and Y. Alef. 2008. "Rapid Assessment of Shelters over Mosaics: Initial Results from Israel." In 9th Conference of the International Committee for the conservation of mosaics (Tunisia, 2005). Lessons learned: reflecting on the theory and practice of mosaics conservation, 193-204. Los Angeles: The Getty Conservation Institute. 
Pesava, P., R. Aksu, S. Toprak, H. Horvath, and S. Seidl. 1999. "Dry deposition of particles to building surfaces and soiling." The Science of the Total Environment 235:25-35. doi: 10.1016/S0048-9697(99)00187-4

Pinna, D., and O. Salvadori. 2008. "Processes of biodeterioration: general mechanisms." In Plant biology for cultural heritage, edited by G. Caneva, M. Pia Nugari and O. Salvadori, 17-34. Los Angeles: The Getty Conservation Institute.

Pio, C.A., M. M. Ramos, and A.C. Duarte. 1997. "Atmospheric aerosol and soiling of external surfaces in an urban environment." Atmospheric Environment 32 (11):1979-1989. doi: 10.1016/S1352-2310(97)00507-4

Saiz Jimenez, C. 2003. "Organic Pollutants in the Built Environment and Their Effect on the Microorganisms." In Effects of Air Pollution on the Built Environment, edited by P. Brimblecombe, 183-226. London: Imperial College Press.

Smith, B.J., S. McCabe, D. McAllister, C. Adamson, H.A. Viles, and J.M. Curran. 2011. "A commentary on climate change, stone decay dynamics and the 'greening' of natural stone buildings: new perspectives on 'deep wetting'." Environmental Earth Sciences 63 (7-8):1691-1700. doi: 10.1007/s12665-010-0766-1

Steiger, M. 2003. "Salts and crusts." In Effects of Air Pollution on the Built Environment, edited by P. Brimblecombe, 133-182. London: Imperial College Press.

Stewart, J., J. Neguer, and M. Demas. 2006. "Assessing the Protective Function of Shelters over Mosaics." The Getty Conservation Institute Newsletter, 16-19. 
Viles, H. 2012. "Greening Stone Conservation: Exploring the Protective Role of Plants and Microbes." In the 12th International Congress on the Deterioration and Conservation of Stone. New York: ICOM-CC.

Viles, H., and A. Gorbushina. 2003. "Soiling and microbial colonisation on urban roadside limestone: a three year study in Oxford, England." Building and Environment 38:1217-1224. doi: 10.1016/S0360-1323(03)00078-7

Viles, H.A., M.P. Taylor, T.J.S. Yates, and S.W. Massey. 2002. "Soiling and decay of NMEP limestone tablets." Science of the Total Environment 292 (3):215-229. doi: 10.1016/S0360-1323(03)00078-7

Watt, D., and B Colston. 2000. "Investigating the effects of humidity and salt crystallisation on medieval masonry." Building and Environment 35 (8):737-749. Doi: 10.1016/S0360-1323(00)00015-9

Webb, A.H., R. J. Bawden, A. K. Busby, and J. N. Hopkins. 1992. "Studies on the effects of air pollutions on limestone degradation in Great Britain." Atmospheric Environment 26B (2):165-181. doi: 10.1016/0957-1272(92)90020-S

West Oxfordshire District Council. 2014. Air Quality Progress Report for West Oxfordshire District Council. Community Services Environmental Protection and Enforcement.

Zanardini, E., P. Abbruscato, N. Ghedini, M. Realini, and C. Sorlini. 2000. "Infuence of atmospheric pollutants on the biodeterioration of stone." International Biodeterioration \& Biodegradation 45:35-42. doi: 10.1016/S0964-8305(00)00043-3 


\section{List of tables}

Table 1: Physical properties of the Portland limestone used in this study. Tests were carried out in the Oxford University Rock Breakdown Laboratory.

Table 2: Means and standard deviations of sulphates and nitrates concentration (ppm) in the first $2 \mathrm{~mm}$ of stone after a year of exposure

Table 3: West Oxfordshire District Council 2013 report on Witney annual mean $\mathrm{NO}_{2}$ concentration $(\mu \mathrm{g} / \mathrm{m} 3)-$ Bias Adjustment factor $=($ National $) 0.80$

Table 4: Means and standard deviations of the amount of sulphur dioxide and nitrogen dioxide $\left(\mu \mathrm{g} / \mathrm{m}^{3}\right)$ in diffusion tubes positioned inside and outside of the shelter at Bishop’s Palace. The blank control tubes were kept covered in a cold and dark room during the same amount of time as the tubes exposed. Limit of detection $=0.05 \mu \mathrm{g} / \mathrm{m} 3$

Table 5: Annual mean $\mathrm{SO}_{2}$ and $\mathrm{NO}_{2}$, total annual rainfall and acidity, and mean weight lost for unsheltered stone after a year of exposure at four NMEP sites and Bishop's Palace (for Bishop’s Palace $\mathrm{SO}_{2}$ and $\mathrm{NO}_{2}$ levels are for October 2013 and rain $\mathrm{H}+$ levels were measured April 2014).

Table 6: Mean concentration of sulphates, nitrates and chlorides (ppm) in Portland limestone sheltered and unsheltered tablets at the NMEP sites and Bishop's Palace after a year of exposure 
Table 1: Physical properties of the Portland limestone used in this study. Tests were carried out in the Oxford University Rock Breakdown Laboratory

\begin{tabular}{lllll}
\hline $\begin{array}{l}\text { Water } \\
\text { absorption at } \\
\text { atmospheric } \\
\text { pressure (Ab) }\end{array}$ & $\begin{array}{l}\text { Water absorption } \\
\text { by } \\
\text { capillarity (C1) - } \\
\text { perpendicular } \\
\text { to the planes of } \\
\text { anisotropy }\end{array}$ & $\begin{array}{l}\text { Water } \\
\text { absorption by } \\
\text { capillarity (C2) - } \\
\text { parallel to the } \\
\text { planes of } \\
\text { anisotropy }\end{array}$ & $\begin{array}{l}\text { Open } \\
\text { porosity (Po) }\end{array}$ & $\begin{array}{l}\text { Apparent } \\
\text { density (pb) }\end{array}$ \\
\hline BS EN & BS EN 1925:1999 & BS EN 1925:1999 & BS EN & BS EN \\
$3755: 2008$ & $226.23 \mathrm{~g} / \mathrm{m}^{2} . \mathrm{s}^{0.5}$ & $231.54 \mathrm{~g} / \mathrm{m}^{2} . \mathrm{s}^{0.5}$ & $1936: 2006$ & $1936: 2006$ \\
$6.96 \%$ & & & & $2100 \mathrm{~kg} / \mathrm{m}^{3}$ \\
\hline
\end{tabular}


Table 2: Means and standard deviations of sulphates and nitrates concentration (ppm) in the first $2 \mathrm{~mm}$ of stone after a year of exposure

\begin{tabular}{lllll}
\hline & & Unsheltered & Sheltered & Control \\
\hline Sulphate & Mean & 31.07 & 86.77 & 30.46 \\
& Stdev & 5.45 & 9.84 & 5.01 \\
Nitrate & Mean & 11.88 & 32.83 & 5.48 \\
& Stdev & 1.76 & 4.84 & 1.74 \\
\hline
\end{tabular}


Table 3: Means and standard deviations of the amount of sulphur dioxide and nitrogen dioxide $\left(\mu \mathrm{g} / \mathrm{m}^{3}\right)$ in diffusion tubes positioned inside and outside of the shelter at Bishop’s Palace. The blank control tubes were kept covered in a cold and dark room during the same amount of time as the tubes exposed. Limit of detection $=0.05 \mu \mathrm{g} / \mathrm{m}^{3}$

\begin{tabular}{llccc}
\hline & & Outside & Under the shelter & Blank \\
\hline $\mathbf{S O}_{2}$ & Mean & LOD & LOD & 0.01 \\
$\mathbf{N O}_{2}$ & Mean & 6.030 & 6.746 & 0.004 \\
& Stdev & 0.904 & 0.901 & \\
\hline
\end{tabular}


Table 4: West Oxfordshire District Council 2013 report on Witney annual mean NO2 concentration $\left(\mu \mathrm{g} / \mathrm{m}^{3}\right)$ - Bias Adjustment factor $=($ National $) 0.80$

\begin{tabular}{llr}
\hline Location & Site type & $\begin{array}{r}\text { Annual Mean } \mathbf{N O}_{2} \\
\text { concentration }\left(\boldsymbol{\mu g} / \mathbf{m}^{3}\right)\end{array}$ \\
\hline Bridge Street, Witney & Roadside & 51.3 \\
Mill Street, Witney & Roadside & 37.9 \\
Early Rd., Witney & Urban background & 14.4 \\
Abbey Rd., Witney & Urban background & 15.5 \\
\hline
\end{tabular}


Table 5: Annual mean $\mathrm{SO}_{2}$ and $\mathrm{NO}_{2}$, total annual rainfall and acidity, and mean weight lost for unsheltered stone after a year of exposure at four NMEP sites and Bishop’s Palace (for Bishop’s Palace $\mathrm{SO}_{2}$ and $\mathrm{NO}_{2}$ levels are for October 2013 and rain $\mathrm{H}^{+}$levels were measured April 2014)

\begin{tabular}{llllllll}
\hline Site & Location & Year & $\begin{array}{l}\mathbf{S O}_{2} \\
\left(\mathbf{\mu g m}^{-3}\right)\end{array}$ & $\begin{array}{l}\mathbf{N O}_{2} \\
\left(\mathbf{p g m}^{-3}\right)\end{array}$ & $\begin{array}{l}\text { Rain } \\
(\mathbf{m m})\end{array}$ & $\mathbf{H}^{+}\left(\mathbf{g m}^{-2}\right)$ & \%Wdry \\
\hline $\begin{array}{l}\text { Wells } \\
\text { Cathedral }\end{array}$ & Somerset & $1987-88$ & 7.8 & 22.9 & 319 & 0.002 & -0.29 \\
$\begin{array}{l}\text { Bovington } \\
\text { Camp }\end{array}$ & Dorset & $1987-88$ & 5.1 & 12.8 & 496 & 0.008 & -0.56 \\
$\begin{array}{l}\text { Lough } \\
\text { Navar }\end{array}$ & Northern & $1987-88$ & 2.7 & 2.5 & 1482 & 0.013 & -0.35 \\
$\begin{array}{l}\text { Strath } \\
\text { Vaich Dam }\end{array}$ & Scotland & $1987-88$ & 2.1 & 2.3 & 1197 & 0.018 & -0.52 \\
$\begin{array}{l}\text { Witney } \\
\text { (this study) }\end{array}$ & Oxford & $2013-14$ & LOD & 6.0 & 486 & 0.001 & -0.06 \\
\hline
\end{tabular}


Table 6: Mean concentration of sulphates, nitrates and chlorides (ppm) in Portland limestone sheltered and unsheltered tablets at the NMEP sites and Bishop's Palace after a year of exposure

\begin{tabular}{lllllll}
\hline Site & Year & \multicolumn{2}{l}{ Sheltered } & \multicolumn{2}{l}{ Unsheltered } & \multicolumn{2}{l}{$\begin{array}{l}\text { Depth } \\
\text { (mm) }\end{array}$} \\
\cline { 3 - 6 } & & $\mathrm{SO}_{4}{ }^{2-}$ & $\mathbf{N O}_{3}{ }^{-}$ & $\mathrm{SO}_{4}{ }^{2-}$ & $\mathrm{NO}_{3}{ }^{-}$ & $(\mathrm{mm}$ \\
Wells Cathedral & $1987-88$ & 2183 & 61 & 153 & $<0.05$ & $0-1$ \\
Bovington Camp & $1987-88$ & 2868 & 109 & & & $0-0.5$ \\
Lough Navar & $1987-88$ & 172 & 20 & 53 & $<1$ & $0-1$ \\
Strath Vaich Dam & $1987-88$ & 144 & 15 & & & $0-1$ \\
Witney (this study) & $2013-14$ & 87 & 33 & 31 & 12 & $0-2$ \\
\hline
\end{tabular}




\section{List of figures}

Figure 1: Open, lightweight shelter at Bishop’s Palace (Witney, England)

Figure 2: a) Optical microscope image (10x) of a biofilm at Bishop’s Palace ruins; b) Optical microscope image (400x) of cells extracted from the biofilm shown in a)

Figure 3: a) Overall colour change relative to baseline expressed as dE*ab (D65); b) Greening of the surface of stone tablets (relative to baseline) expressed as da* (D65); c) darkening/lightening of stone tablet surfaces expressed as $\mathrm{dL}^{*}$ (D65) means and standard deviations for sheltered and unsheltered (outside) positions after $6(n=3), 12$ $(n=3)$ and 18 months $(n=6)$.

Figure 4: a) Optical microscope image of biological growth on a tablet placed outside the shelter (18 months of exposure); b) SEM image of an unsheltered sample showing a biological community with filamentous cells covered with calcareous deposits, suggesting precipitation of solubilised calcium (18 months of exposure).

Figure 5: Concentration of a) sulphates, b) nitrates and c) chlorides (in ppm) in unsheltered, sheltered and control tablets after 6,12 and 18 months of exposure Figure 6: Means and standard deviations of weight change (\%Wdry) in unsheltered (a) and sheltered (b) tablets after 6,12 and 18 months of exposure 


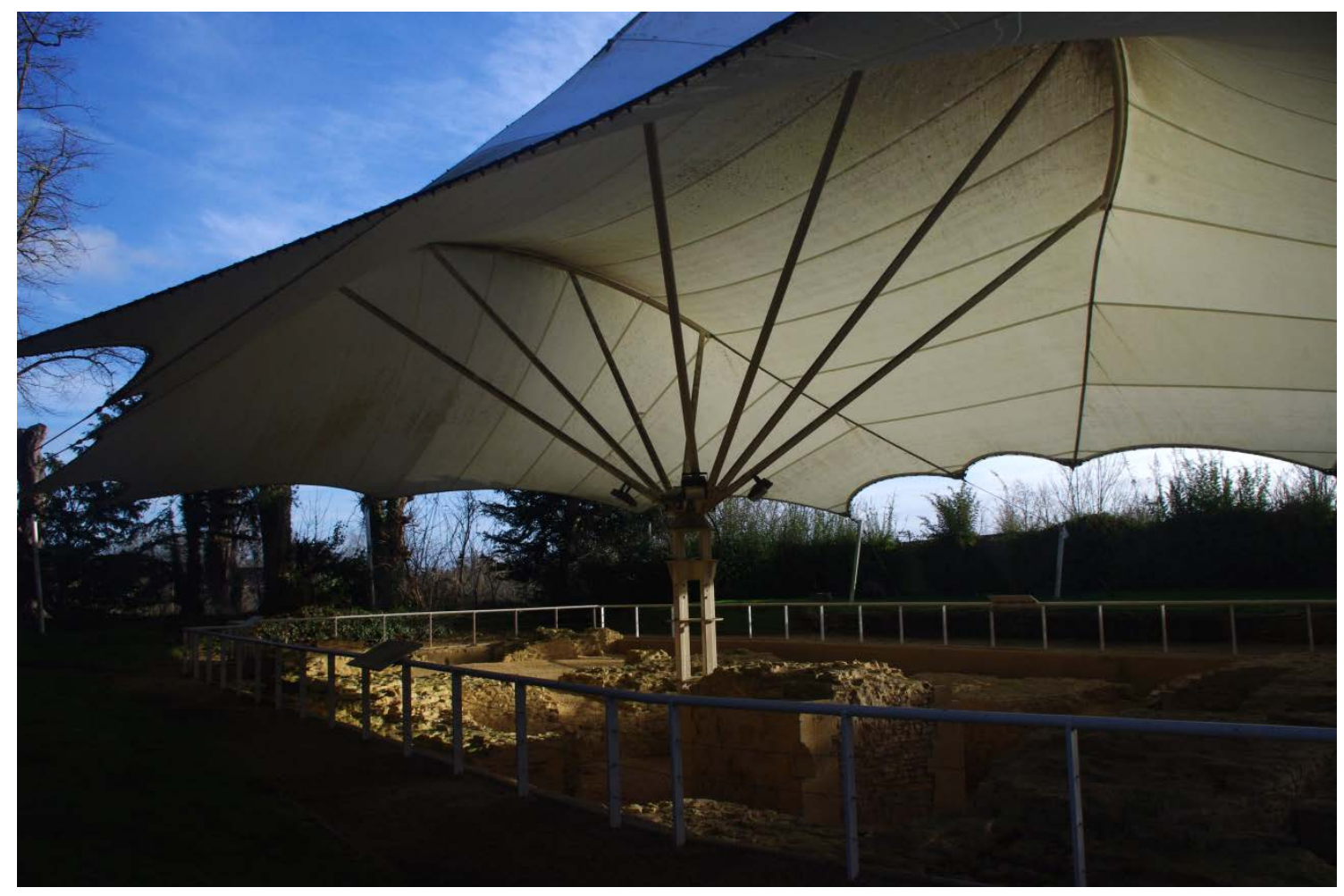

Figure 1: Open, lightweight shelter at Bishop’s Palace (Witney, England) 


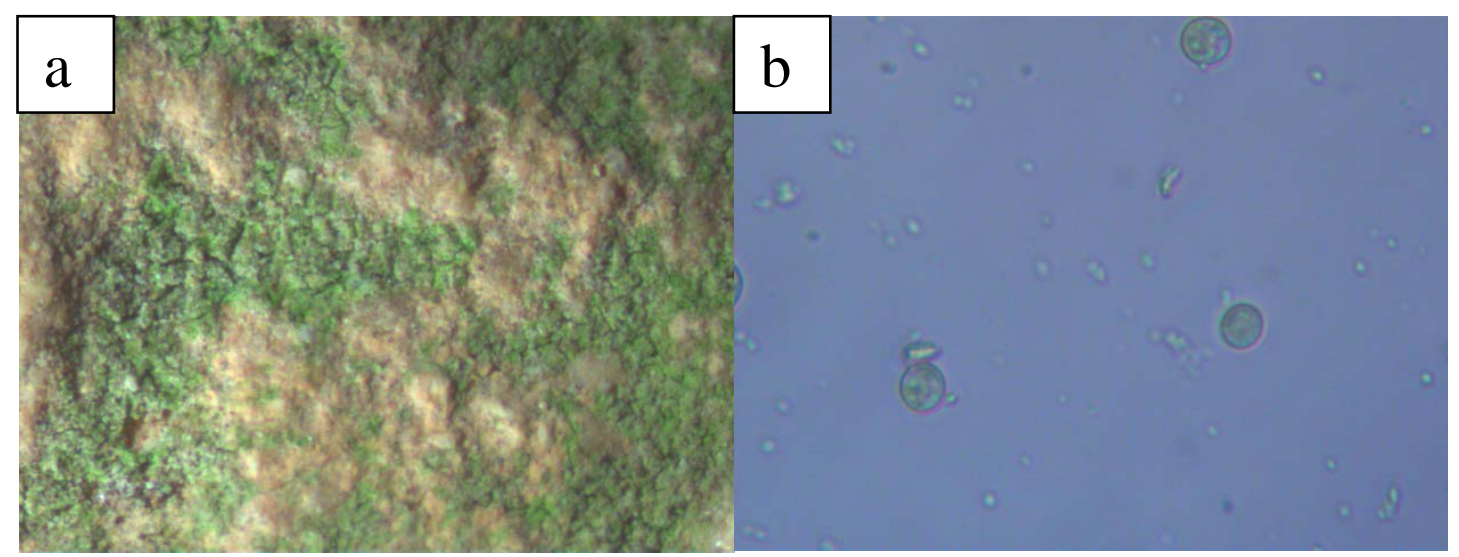

Figure 2: a) Optical microscope image (10x) of a biofilm at Bishop’s Palace ruins; b) Optical microscope image (400x) of cells extracted from the biofilm shown in a) 
a)

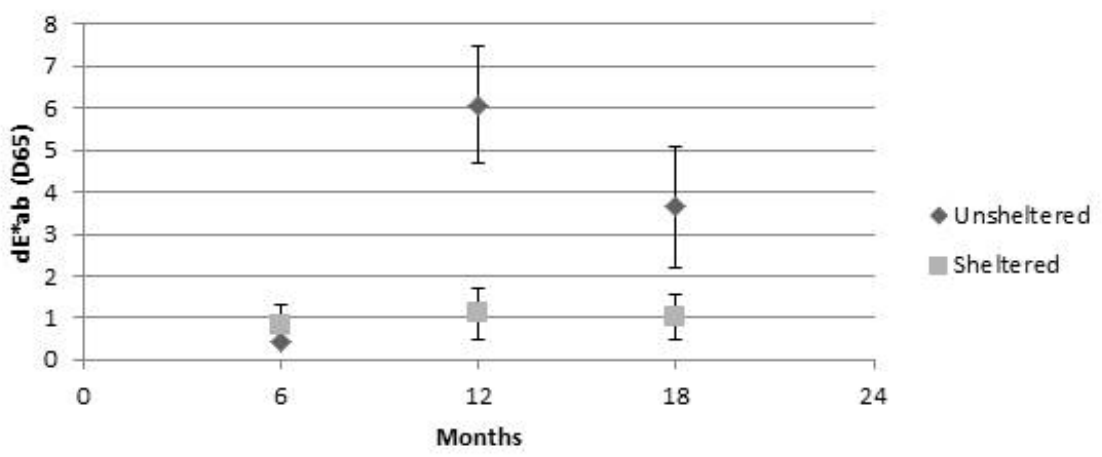

b)

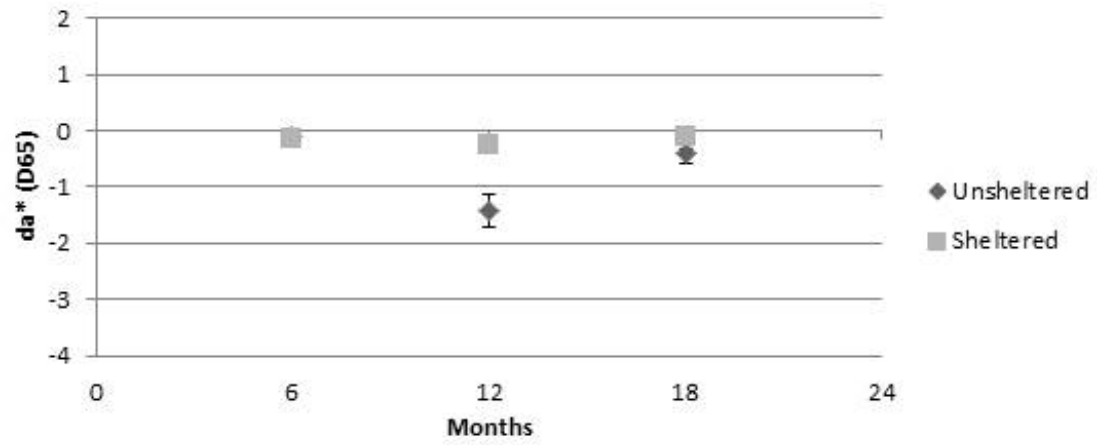

c)

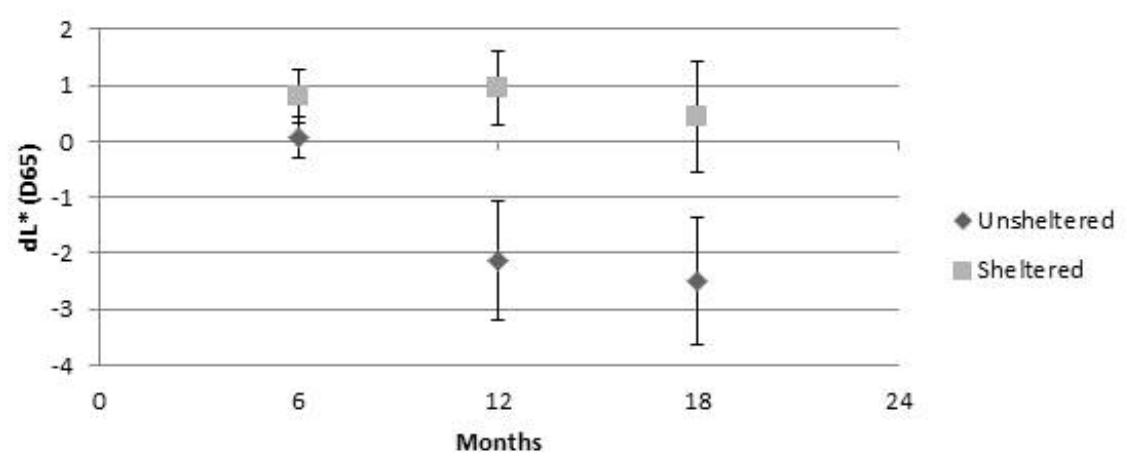

Figure 3: a) Overall colour change relative to baseline expressed as dE*ab (D65); b) Greening of the surface of stone tablets (relative to baseline) expressed as da* (D65); c) darkening/lightening of stone tablet surfaces expressed as $\mathrm{dL}^{*}$ (D65) means and standard deviations for sheltered and unsheltered (outside) positions after $6(n=3), 12(n=3)$ and 18 months $(n=6)$. 


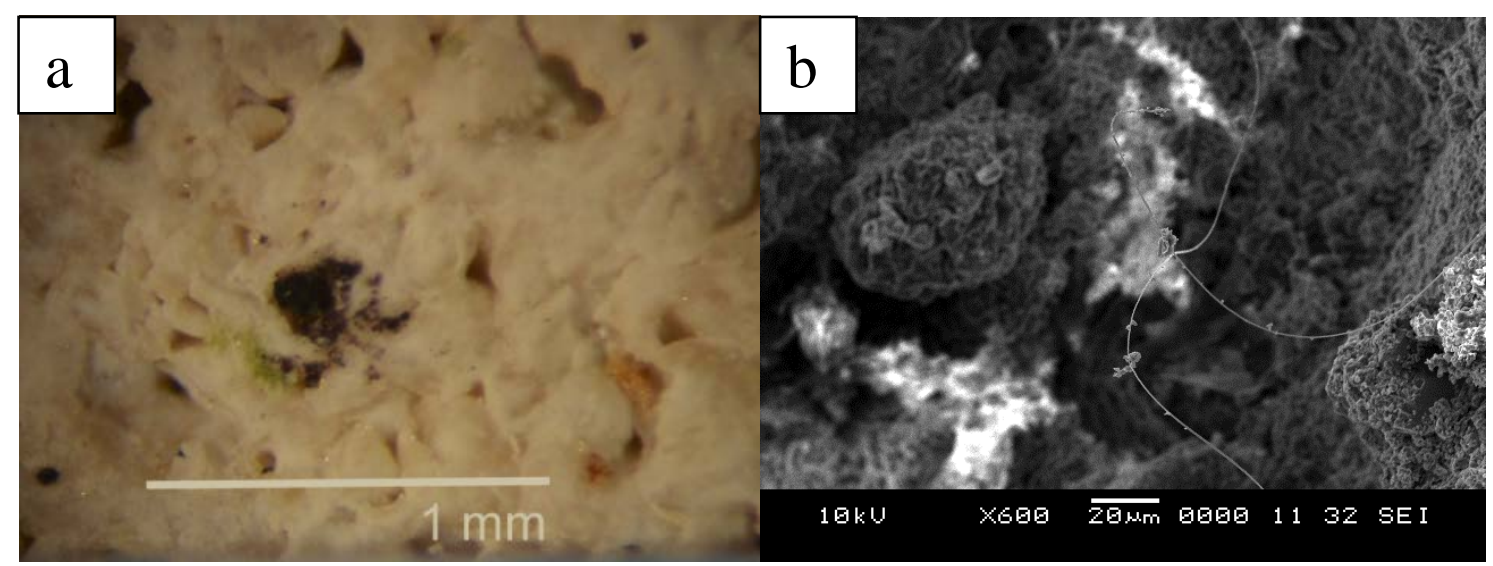

Figure 4: a) Optical microscope image of biological growth on a tablet placed outside the shelter (18 months of exposure); b) SEM image of an unsheltered sample showing a biological community with filamentous cells covered with calcareous deposits, suggesting precipitation of solubilised calcium (18 months of exposure). 
a)

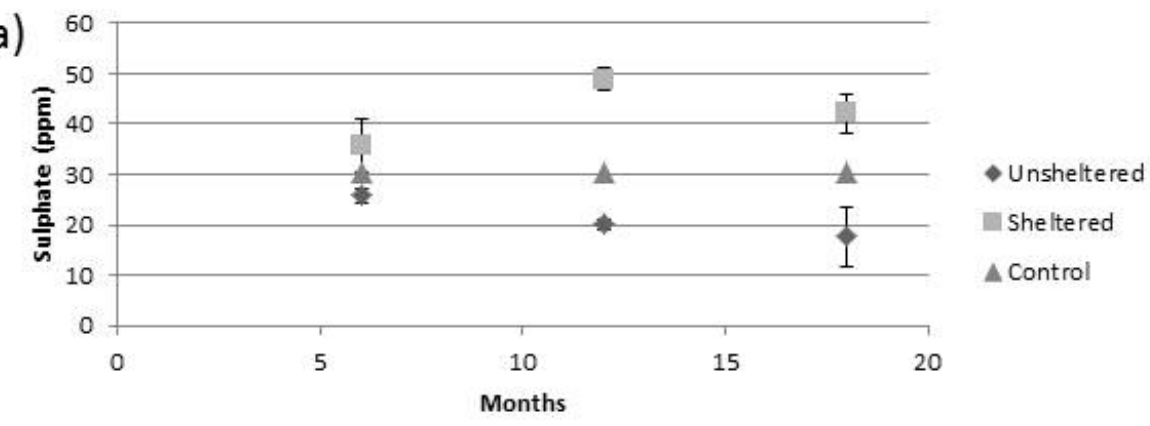

b)

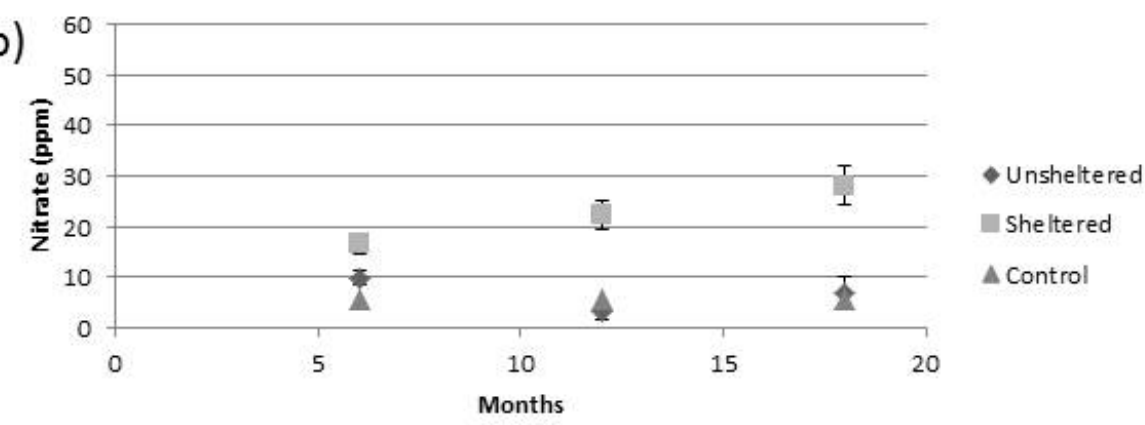

c)

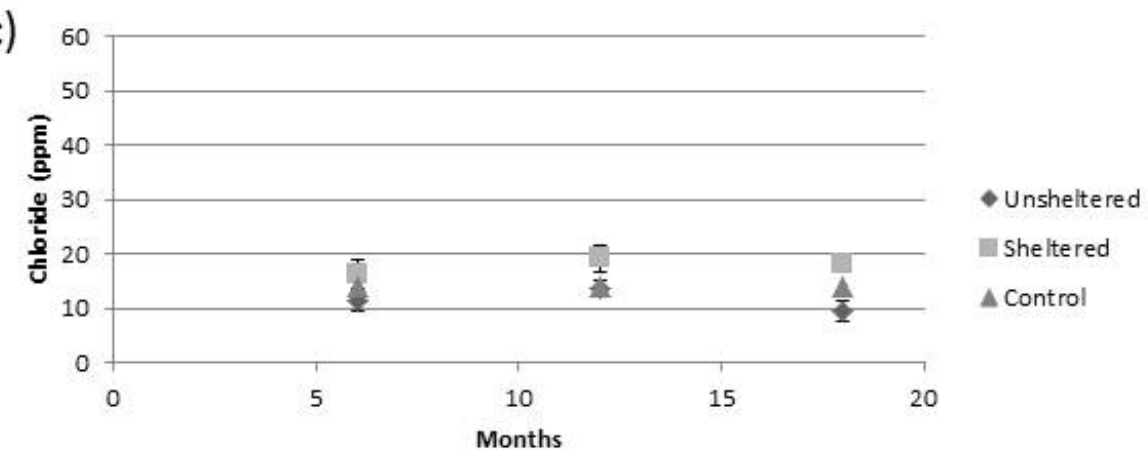

Figure 5: Concentration of a) sulphates, b) nitrates and c) chlorides (in ppm) in unsheltered, sheltered and control tablets after 6,12 and 18 months of exposure 
a)

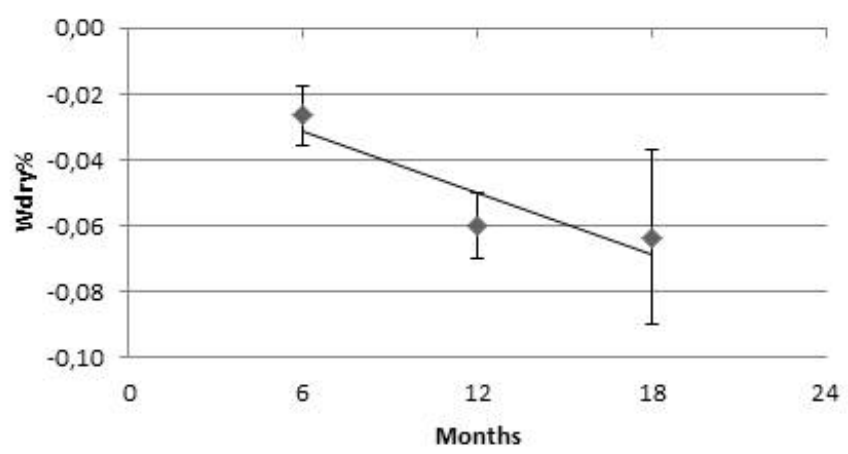

b)

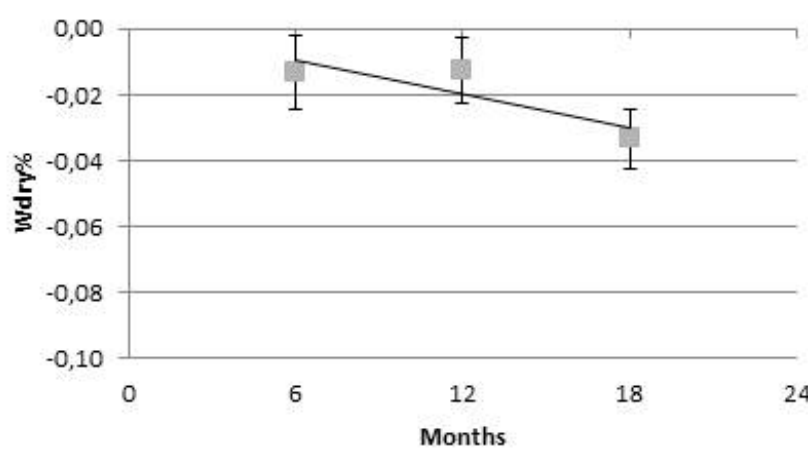

$y=-0,0031 x-0,013$

$R^{2}=0,8196$

$y=-0,0017 x+0,0003$ $R^{2}=0,7378$

Figure 6: Means and standard deviations of weight change (\%Wdry) in unsheltered (a) and sheltered (b) tablets after 6, 12 and 18 months of exposure 